\title{
Carbon Sequestration in the Rain Forest: Alternatives Using Environmentally Friendly Biotechnology
}

\author{
Marcos S. Buckeridge \\ Marcos P.M. Aidar
}

Biota Neotropica v2 (n1) http://www.biotaneotropica.org.br/v2n1/pt/abstract?point-of-view+BN00902012002

Date Received: March, 26, 2002

Accepted: April, 04, 2002

Marcos S. Buckeridge (msbuck@usp.br) e Marcos P.M. Aidar (maidar@uol.com.br)

Instituto de Botânica, Seção de Fisiologia e Bioquímica de Plantas

CP. 4005 CEP 01061-970 São Paulo, SP, Brazil

\begin{abstract}
As carbon dioxide increases on Earth atmosphere, the rise in average temperatures may provoke changes in the environment that could damage civilisation as we know it. As a result, the need to sequester carbon becomes urgent, and one of the options we have is to use the potential of the forests to do it by enhancing assimilation of $\mathrm{CO}_{2}$ through photosynthesis. However, if we consider the use of plants to increase carbon sequestration, a problem that looms is that species often acclimate and actually reduce $\mathrm{CO}_{2}$ assimilation through feedback mechanisms of the sugars that are the product. In the present article, we propose that some biochemical pathways, such as those in control of photosynthesis, carbohydrate metabolism and assimilation, and cellulose and polysaccharide synthesis, that might be targeted so that $\mathrm{C}$ sequestration, could be increased. Genetic control of metabolic pathways is now among the technologies available. Although genetic modification of native plants is controversial, according to the forecasts the concentration of atmospheric $\mathrm{CO}_{2}$ will double in just 50 years, and, therefore, we may have few options short of greatly reducing output. Fortunately, we already know a few candidate genes to be targets for genetic manipulation, and in this short article we discuss some environmentally friendly approaches to the problem.
\end{abstract}

Keywords Global change, Carbon Sequestration, Photosynthesis, Rain Forest, Sugar Sensing, Cellulose synthesis, Gene therapy

\section{Resumo}

Com o recente aumento na concentração atmosférica de $\mathrm{CO}_{2}$ e o conseqüente aumento nas médias de temperatura, as alterações ambientais previstas poderiam causar danos à civilização na forma em que conhecemos. Como consequiência desses previsões, a necessidade de seqüestrar carbono está se tornando urgente e uma das opções que temos é o uso do potencial que as florestas tropicais têm de assimilar $\mathrm{CO}_{2}$ através da fotossíntese. No entanto, se considerarmos o uso de plantas para aumentar o seqüestro de carbono, haverá um problema que é o fato de muitas espécies vegetais aclimatarem, o que significa uma inibição na assimilação de $\mathrm{CO}_{2}$ pela produção de açúcares. No presente artigo, propomos que algumas rotas bioquímicas poderiam ser alteradas em plantas de forma a controlar a fotossíntese, metabolismo de carboidratos e também a síntese de celulose. Com isso talvez se pudesse aumentar o seqüestro de carbono. Dentre as tecnologias disponíveis, aquela que apresenta um rápido desenvolvimento recente é o controle do metabolismo através de alterações no controle genético de vias metabólicas. Ainda que isto seja controverso, o tempo está correndo e de acordo com as previsões, nós podemos ter um pouco mais de 50 anos antes que a concentração de $\mathrm{CO}_{2}$ atmosférico dobre. Considerando que já conhecemos alguns genes que poderiam ser alvo de transformações de plantas e que estas técnicas estão melhorando com grande velocidade, neste trabalho nós discutimos algumas das formas ambientalmente saudáveis para abordar o problema.

Palavras-chave Mudanças Climáticas Globais, Seqüestro de Carbono, Fotossíntese, Floresta Tropical, Síntese de Celulose, Metabolismo de Açúcares, Terapia Gênica 
During the last years, the issue of the rise in atmospheric $\mathrm{CO}_{2}$ concentration due to fuel burning and its deleterious effects on Earth's life became a fact and, as a consequence, a new science named Global Change Biology has emerged. An even bigger problem for humans may be that the consequences of the $\mathrm{CO}_{2}$ increase might be such that many people are starting to accept that this situation may seriously threaten the existence of civilisation as we know.

There has been controversy among scientists, some reanalysing data available and concluding that human activities are responsible for atmospheric changes since industrial revolution and others use the same set of data to propose that Earth has gone through this situation several times already and this change in $\mathrm{CO}_{2}$ concentration is natural.

An immediate "solution" to the problem, in case we admit that the first hypothesis is likely to be correct, would be to search for sources of energy that do not emit or emit less $\mathrm{CO}_{2}$. However, this is not as trivial as it seems. Our entire economic system is based on technologies that use oil and although our technology develops quite quickly, any change in the course of the system can not be abrupt. The system is analogous to an enormous transatlantic cruise ship: changing direction too quickly may not sink it, but will certainly break many things inside it and also hurt a lot of people. We then came to a situation where a group of Nations is pleading for collective actions that would decrease $\mathrm{CO}_{2}$ emission even if the cost is to decrease economic activity for a while. But this strategy was not accepted by the United States, which is the biggest economy and therefore the most important country regarding $\mathrm{CO}_{2}$ emission.

As a result of this situation, the emissions have decreased and probably will not fall for a certain time in the future. In fact, if it just continues with the same pace now in course, the concentration of $\mathrm{CO}_{2}$ will rise to approximately 720 ppm by 2050 , which is double that we have today.

This poses what is probably one the most phenomenal problems of our time. We were placed in a very sophisticated spaceship, but don't know how many of the controls work. Even worse, the handbook is incomplete so that we have still to discover how many parts of the ship work!

Lets look at the problem from another perspective now. If the problem is the rise in the concentration of the principal greenhouse gas that contain carbon $\left(\mathrm{CO}_{2}\right)$, our goal has to be to find ways to sequestrate it with higher efficiency. In order to find such a mechanism, we have to understand what laws govern carbon cycle on Earth so that we would find out what buttons to press in order to increase sequestration or keep carbon arrested for a longer time.

Here, plant life on the planet becomes an issue of great importance. The reason for all that importance is that plants are simply the most efficient and the most widespread $\mathrm{CO}_{2}$ sequestration living mechanism available in our planet. They do that by a complex mechanism in which the photosynthetic system is coupled with biosynthesis of cellulose. The complete mechanism can be divided into three parts: 1) carbon dioxide absorption; 2) synthesis of simple sugars (such as glucose) and 3) synthesis of cellulose, which is the most abundant, widespread and compact carbon compound in Nature. This division gives at least three points that can be explored for control points.

The three integrated mechanisms are represented in Figure 1. It can be clearly seen in these diagrams that the carbon assimilated by plant leaves may be respired or accumulated as cellulose (Figure 1A). The direct result of the work of these integrated mechanisms is plant growth, which ultimately determine the patterns of development of entire forests.

Currently, carbon dioxide assimilation is by far the most studied aspect regarding the response of plants to the global changes in atmospheric $\mathrm{CO}_{2}$. Several experiments have been and are being now performed to evaluate the response of plant species to elevated $\mathrm{CO}_{2}$ concentrations. This is because such differences in response are likely to affect the composition of naturally regenerating biomes.

Some patterns of response are starting to emerge from the results produced. It has been forecasted, for example, that under certain circumstances, $\mathrm{C} 4$ plants would lose advantages over $\mathrm{C} 3$ photosynthetic systems acquired during millions of years of evolution. One of the main advantages of $\mathrm{C} 4$ plants over $\mathrm{C} 3$ is that the former are more efficient in using $\mathrm{CO}_{2}$ and water. This is certainly an advantage in regions of the planet where temperature is high and water availability is low, such as the edges of deserts. As a consequence of an increase in $\mathrm{CO}_{2}$ concentration, such advantages may be lost in several places on Earth and this may, so to speak, revert the course of evolution by changing competition patterns between $\mathrm{C} 4$ and $\mathrm{C} 3$ plants, because the $\mathrm{C} 3$ plants will become more efficient at using $\mathrm{CO}_{2}$ and water. Although this aspect of $\mathrm{C} 3$ versus $\mathrm{C} 4$ plants highlights important ecological aspects of the effect of the rise in $\mathrm{CO}_{2}$ concentration on biodiversity, it is of relatively minor importance for the issue of carbon sequestration. This because the potential of $\mathrm{C}$ sequestration is much higher in the forests, where the amount of biomass is comparatively much higher.

Furthermore, C3 plants make up more than $95 \%$ of all plants and some work has also been performed regarding $\mathrm{CO}_{2}$ assimilation by photosynthesis. One interesting analysis has been performed by Kerstiens (2001). He used recent literature data on responses to high $\mathrm{CO}_{2}$ by several temperate species and found that the shadetolerant ones respond with a bigger increase in biomass in relation to shade-intolerant species. Our results seem to corroborate Kerstians hypothesis. We found that leaves of growing seedlings of Hymenaea courbaril (jatobá), a shade tolerant climax tropical tree from the rain forest, respond to high $\mathrm{CO}_{2}(720 \mathrm{ppm})$ by doubling $\mathrm{CO}_{2}$ assimilation, with higher leaf area and dry mass. The explanation for this behaviour is that their leaves present saturation of assimilation rate only to $\mathrm{CO}_{2}$ at concentrations as high as 
$1000 \mathrm{ppm}$.

Although results like these are likely to help understanding how different species will respond to the expected $\mathrm{CO}_{2}$ rise in atmospheric concentration, they do not explain why species respond in one way or the other. This is of great value if one needs to known how to control assimilation. One step in this direction was given by Prof Carlos Labate, at ESALQ-USP (Department of Genetics). He managed to transfer one of the genes of the system of light absorption (Light Harvesting Complex II or LHC II) of pea leaves to tobacco and as a result, he obtained transgenic plants that increased mass accumulation in ca. $30 \%$. Labate appears to have found one of the buttons that might be pressed in case we need efficient, fast and renewable increase in carbon sequestration. He is now trying the same strategy with Eucalyptus to check whether it could be done with tree species. It has to be highlighted that in this case, a transformation technique of a nuclear gene was performed. Alternatively, there would be some advantage from the environmental point of view when chloroplasts are genetically engineered because usually the paternal plastids are disintegrated during ovule fecundation, lowering the potential environmental danger of these plants to near zero (Daniell et al 2002).

Supposing that we have to use this type of biotechnology to increase $\mathrm{C}$ sequestration, we still would not be dealing with the great potential that we really have, i.e. the forests. In the tropical forests, plant biodiversity is very high and we do not know yet whether photosynthetic and carbohydrate metabolism systems are as diverse as the species that hold them. However, we can certainly estimate that these systems are pretty conserved in most $\mathrm{C} 3$ plants.

This brings us to another issue that could present some further control buttons: photosynthesis acclimation through carbohydrate metabolism.

It is becoming clear that most plants are capable of sensing their internal carbohydrates (sucrose) concentration and also its direction of flow, so that photosynthesis itself might be adjusted to "avoid" excess of $\mathrm{CO}_{2}$ assimilation (Figure 1C). As a result, a decrease in $\mathrm{CO}_{2}$ assimilation can be observed after a longer period in high $\mathrm{CO}_{2}$ concentration. This issue has been referred to as "sugar sensing mechanism" (Smeekens, 2000) and a few genes that encode for key enzymes in the process may be considered candidates as control buttons (e.g. RUBISCO, hexokinase and sucrose synthase). Controlling sugar sensing could probably switch off acclimation (in cases where it occurs) and allow the flow of sugars to the synthesis of cellulose and non cellulosic polysaccharides (Figure 1D).

Yet a third "metabolic region" where we could find buttons to press is the pathway to cellulose synthesis. We know that the precursors come from sucrose, via UDPglucose and this part of the pathway is under the control of the "sugar sensing mechanisms". However, it is also important to be able to control synthesis at the membrane level. The fact that the synthases related to cellulose are buried into membranes (plasma or Golgi membranes) has been the major constraint for the advancement of this field. This is simply because the techniques developed for protein purification during the last century could hardly be applied to membrane proteins.

In 1996, Pear et al. (1996) found that a cotton gene appeared to encode the cellulose synthase catalytic subunit (CesA). After random sequencing of a cotton cDNA library at the beginning of secondary wall synthesis, two CesA genes were isolated. The deduced amino acid sequence of these genes were found to share regions of similarity with the bacterial CesA proteins that had previously been characterised. By usage of conserved domains that appear to be present in most plants, we now know that CesA is a large gene family (Carpita and Vergara, 1998) and some members might be future targets to increase $\mathrm{C}$ sequestration in plants. Our research group found many members of the CesA family in sugar-cane (SUCEST-FAPESP; Lima et al. 2001) and some are good candidates to study the effects on $\mathrm{C}$ sequestration in the near future, by studying the responses to high $\mathrm{CO}_{2}$ of transgenic plants produced either by overexpression or suppression of specific CesA genes.

Using or not biotechnological techniques of the genomic era to cope with the issue of $\mathrm{C}$ sequestration will depend on many aspects. Among them, we could mention the fact that we do not know what are the environmental effects of using genetically modified plants. Even worse, according to the forecasts, we shall probably have no time to test them anyway. There are also ethical problems involved and most people would not accept the usage of molecular techniques for political or religious reasons.

We can now restate the problem of global change, $\mathrm{C}$ sequestration, forests and the genomic biotechnology in the following way.

We have approximately 50 years to find a way to improve carbon sequestration in plants using whatever technology is available, because if the forecasts are fulfilled, civilisation as we know may not remain organised. We have developed techniques of genetic transformation of plants and we know a little about which metabolic pathways to change. However, even if we start a program of plant transformation now in order to produce high carbon assimilation by genetically modified organisms (GMOs), there will not be enough time for these forest trees to develop in only 50 years. This would raise questions such as: where to grow these GMOs? What are the future ecological consequences of the existence of GMO forests?

Supposing that we will really need molecular techniques to solve the $\mathrm{C}$ sequestration problem, we would have to find a way to do it, so that we could minimise future problems. This strategy would include the use of techniques that could be applied to existing forest species and the transformations would have to have minimal ecological impact in the future.

Although such a solution seem to be unreachable or a theme of a science fiction book, some authors are already proposing the use of Plant Gene Therapy (PGT) 
for improvement of crops. PGT consists of using chimaeric RNA/DNA oligonucleotide-directed gene targeting. These molecules have been shown to direct site-specific base changes in plant cells, without introducing foreign DNA into the genome (May and Kmiec, 2001). Some advantages of PGT techniques are that 1) plants obtained in this way can not be considered as GMOs, since there is no insertion of a foreign gene and 2) the progeny from modified plants by this technique have been shown to inherit gene conversions in a Mendelian fashion. One disadvantage regarding $\mathrm{C}$ sequestration in the forest is that with this technique, it is not yet possible to perform genetic changes in adult plants. However, this may become feasible in the near future, since some authors are already finding evidence for the existence of an RNA based signalling network that potentiates the control of gene expression at the whole-plant level (Lucas et al. 2001).

The decision to use or not such techniques may become less a matter of willing and more of a necessity in the near future. Although it may be premature and dangerous, we have to be ready to use the best of our technology in case this turns to be our last option. If our patient is really ill, nearly terminal: shall we use gene therapy to save it?

\section{Acknowledgements}

The authors thank the colleagues Marilia Gaspar, Marco Tiné and Miguel Minhoto for the critical reading of this article and also Nick Carpita and Carlos Labate for the useful discussions about the basic ideas involved in the argument.

\section{References}

CARPITA, N.C. and Vergara, C.E. 1998. A recipe for cellulose. Science 279: 672673.

DANIELL, H,. Khan, M.S. and Allison, L. (2002) Milestones in chloroplast genetic engineering: an environmentally friendly era in biotechnology, Trends in Plant Science 7: 84-91.

KERSTIENS, G. (2001) Meta-analysis of the interaction between shad-tolerance, light environment and growth response of woody species to elevated $\mathrm{CO}_{2}$. Acta Oecologica 22: 61-69.

LIMA, D.U., Santos, H.P., Tiné, M.A., Molle, F.D. \& Buckeridge, M.S. (2001) Patterns of expression of cell wall related genes in sugar cane. Genetics and Molecular Biology (in press)

LUCAS, W.J. Yoo, B.C., Kragler F. (2001) RNA as a longdistance information macromolecule in plants. Nat. Rev. Mol. Cell. Biol. 2: 849-857
MAY, G.D. and Kmiec, E.B. (2000) Plant gene therapy: crop varietal improvement through the use of CHIMAERIC RNA/DNA oligonucleotide-directed gene targeting. AgBiothechNet 2: ABN053

PEAR, J.R., Kawagoe, Y., Schreckengost, W.E., Delmer, D.P. and Stalker, D.M. (1996) Higher plants contain homologs of the bacterial celA genes encoding the catalytic subunit of cellulose synthase. Proc. Natl. Acad. Sci. USA 93: 1263712642.

SMEEKENS, S. 2000. Sugar-induced signal transduction in plants. Annu. Rev. Plant Phys. Plant Mol. Biol. 51:49-81.

Títle: Carbon Sequestration in the Rain Forest:

Alternatives Using Environmentally Friendly

Biotechnology

Authors: Marcos S. Buckeridge e Marcos P.M. Aidar

Biota Neotropica, Volume 2, número 1, 2002 -

http://www.biotaneotropica.org.br/v2n1/pt/abstract?point -of-view+BN00902012002

Date Received: March, 26, 2002

Accepted: April, 04, 2002

ISSN 1676-0611 

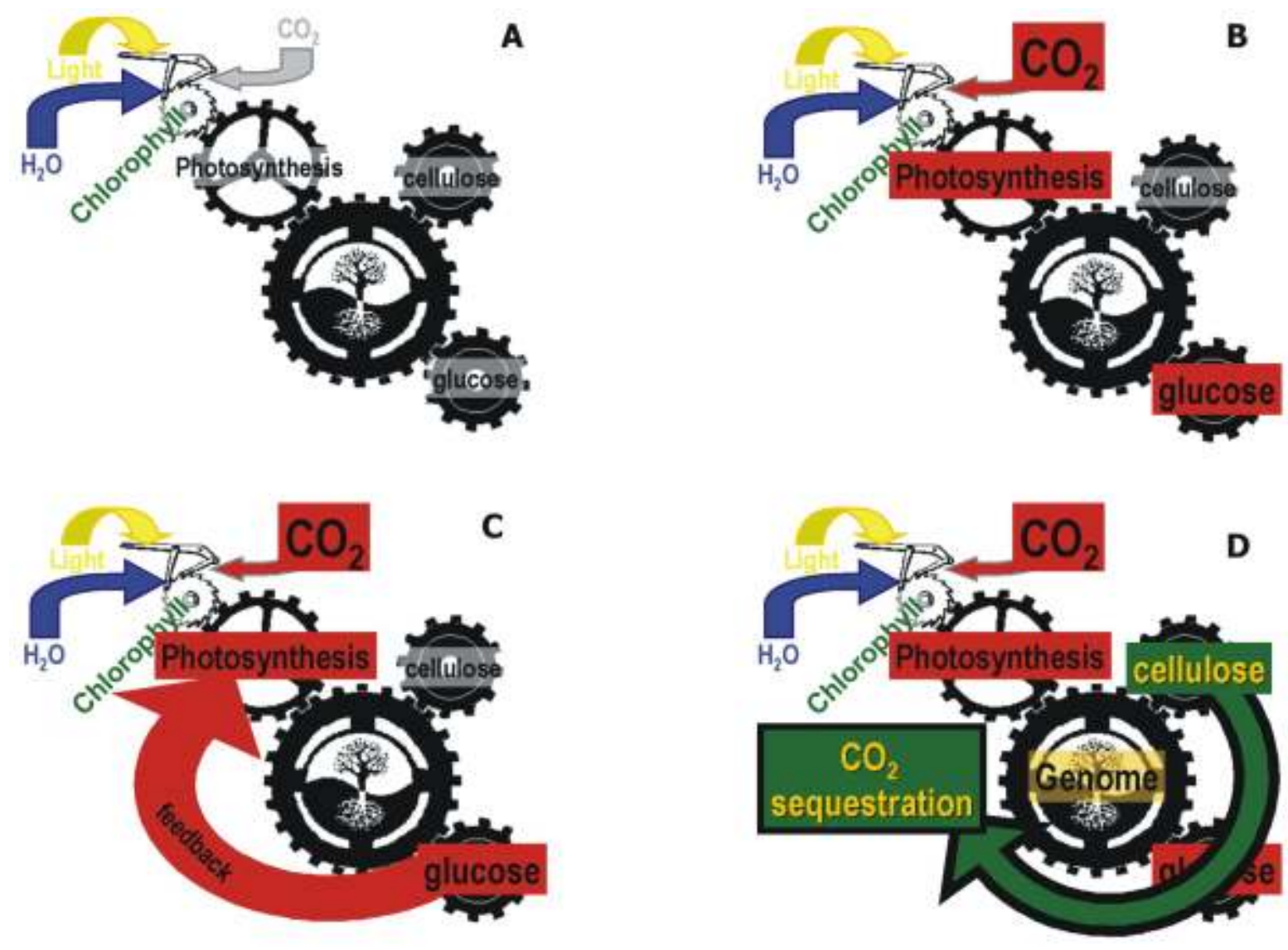